\title{
Pemetaan Struktur Massa Air di Muara Sungai Jeneberang Dengan
}

\section{Menggunakan ArcGis}

\author{
Riswal Karamma1, Muhammad Saleh Pallu², Muh. Arsyad Thaha', \\ Mukhsan Putra Hatta ${ }^{2}$ \\ 1,2,3,4 Departemen Teknik Sipil, Fakultas Teknik, Universitas Hasanuddin \\ e-mail: ${ }^{1}$ riswalchiwal@gmail.com
}

\begin{abstract}
Abstrak
Estuary adalah tempat pertemuan air tawar dan air asin yang di pengaruhi oleh pasang surut. Pengaruh pasang surut terhadap sirkulasi aliran seperti kecepatan, profil muka air dan intrusi air asin di estuari dapat sampai jauh ke hulu sungai tergantung pada tinggi pasang surut. Penelitian ini dilakukan di Muara Sungai Jeneberang dengan mengukur langsung masa air yaitu salinitas, temperature, dan densitas. Penelitian dilakukan untuk memetakan pola sebaran dan stratifikasi struktur massa air secara spasial pada saat spring tide dan neep tide di Muara Sungai Jeneberang pada saat kondisi pasang menuju surut dan pada saat kondisi surut menuju pasang. Tahapan dalam pengolahan data menggunakan tools Sistem Informasi Geografis/Geographic Infromation System (ArcGis) yang sebelumnya dilakukan pengukuran, pengamatan, perekaman, dan pemetaan. Data hasil pengukuran kemudian dibuat dalam model spasial dengan menggunakan Aplikasi ArcGis untuk melihat pola sebaran struktur massa air akibat pengaruh pasang surut. Pola sebaran dan pelapisan massa air ini diperlihatkan secara spasial pada saat spring tide dan neep tide, pada kondisi pasang menuju surut dan kondisi surut menuju pasang. Pola sebaran struktur massa air secara spasial ini perlu ditambahkan dengan memperlihatkan pola sebabarannya secara vertical, sehingga dapat melihat profil kolom air dan kondisi pencampuran yang terjadi akibat pengaruh pasang surut
\end{abstract}

Kata Kunci: ArcGis, Estuary, Massa Air, Salinitas

\section{Pendahuluan}

Estuary adalah perairan semi tertutup yang dipengaruhi oleh pasang dan surut air laut sehingga terjadi percampuran massa air [1][2]. Muara Sungai Jeneberang mendapat pengaruh pasang surut air laut dengan karakteristik pasang semi diurnal [3]. Kejadian pasang surut akan mentransportkan air dari laut menuju perairan pantai pada saat pasang dan dari perairan pantai ke laut lepas pada saat surut [4]. Di dalam perairan estuari sering kali didominasi oleh proses pencampuran. Distribusi salinitas di perairan estuari sangat dipengaruhi oleh kedalaman, arus pasut, aliran permukaan, penguapan dan air tawar yang masuk ke perairan laut. Distribusi salinitas di lapisan tercampur "Mixed layer" menunjukkan nilai relatif lebih rendah dari pada di lapisan dalam. Salinitas merupakan faktor penting bagi penyebaran organisme perairan laut dan oksigen dapat merupakan factor pembatas dalam penentuan kehadiran makhluk hidup di dalam air.[5][6]. Perkiraan distribusi salinitas juga telah dilakukan pada muara Sungai Jeneberang dengan alat ArcGIS namun belum mengkaji masalah stratifikasi stuktur massa air secara mendalam [7].

Penelitian ini bertujuan untuk memetakan pola sebaran dan stratifikasi struktur massa air secara spasial pada saat spring tide dan neep tide di Muara Sungai Jeneberang.

\section{Metode}

a. Lokasi Penelitian

Lokasi kajian dilakukan di Muara Sungai Jeneberang. Terletak pada koordinat UTM 50S UTM $763000 \mathrm{~m}$ E $767000 \mathrm{~m}$ E dan $9426000 \mathrm{~m}$ S-9426000m $\mathrm{S}$

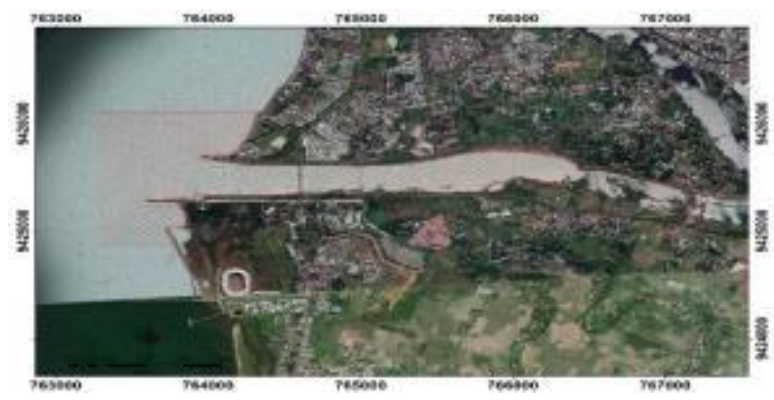

Gambar 1. Lokasi penelitian di Muara Sungai Jeneberang

\subsection{Alat yang digunakan}

Alat yang digunakan dalam peneltian ini: GPS Hand, GPS Echosounder, Waterpass, Logger, Acoustic Doppler Current Profiler (ADCP) atau sejenisnya dan Conductivity Temperatur Depth $(C T D)$ atau sejenisnya.

\subsection{Pengukuran data arus}

Pengambilan data arus dengan metode euler. Pengukuran menggunakan ADCP Argonaut SonTek 
XR dengan panjang gelombang sensor beam 0.75 mhz dan autonomous multi - cell system.
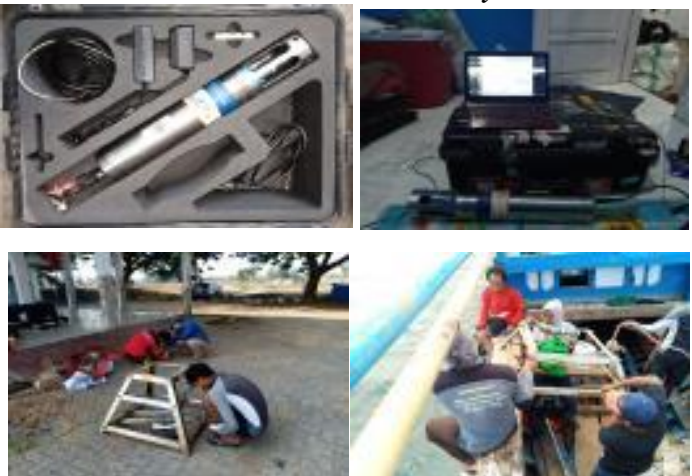

Gambar 2. Alat yang digunakan

Metode euler merupakan prinsip kerja ADCP dalam pengukuran arus dengan konsep mengikuti gerak partikel air dengan menembakan single beam pada kedalaman tertentu dengan pembagian layer yang telah disetting. ADCPArgonaut SonTek XR pada masing - masing lokasi diletakan di kedalaman $\pm 3,6$ meter untuk stasiun 1 dan kedalaman $\pm 2,7$ meter untuk stasiun 2. Sensor membentuk sudut terhadap sumbu tegak sebesar $20^{\circ} \mathrm{ke}$ atas dan membentuk sistem koordinat kartesian terhadap komponen arus pada arah u (barat-timur/E), v (utaraselatan/N), dan $\mathrm{z}$ (vertikal kolom air/U). Posisi peletakan ADCP (accoustic doppler current profile) Argonaut SonTek XR adalah sebagai berikut:

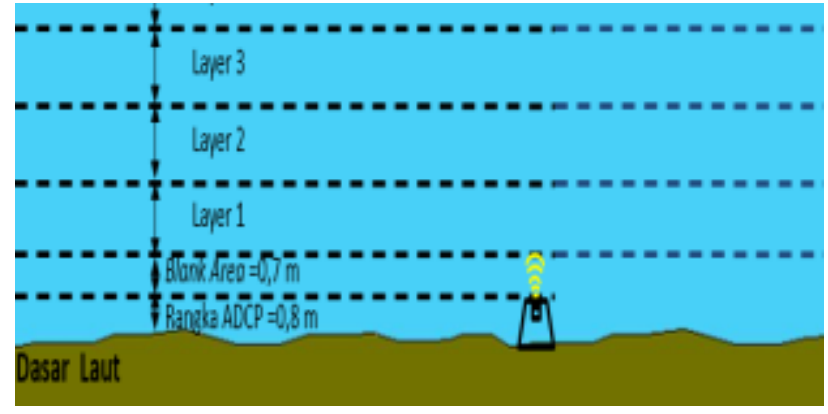

Gambar 3. Sketsa pembagian layer pada kinerja ADCP

\subsection{Perekaman Pasang Surut (Tide Recorder)}

Perekaman pasang surut dalam menentukan duduk tinggi muka air dilaksanakan selama $15 \times 24$ jam dengan sample interval sebanyak 5 menit, dan variasi kedalaman berkisar antara $0-3$ meter, pada dua stasiun pengukuran arus laut, di Muara Sungai Jeneberang.

\subsection{Pengukuran Batimetri}

Pemeruman batimetri bertujuan untuk menentukan bentukan dasar permukaan laut (seabed surface) pada luasan area perairan muara Sungai
Jeneberang dengan luas terukur di daerah luar muara sungai adalah $1 \mathrm{~km} \times 1 \mathrm{~km}$. Pengambilan data batimetri dilakukan dengan perangkat Echo Sounder Garmin 585 yang terdiri dari display set, transducer, antena dan aki $a c c u$, frekuensi sonar beam 50/200 khz untuk akurasi $0,1 \mathrm{~m}$.

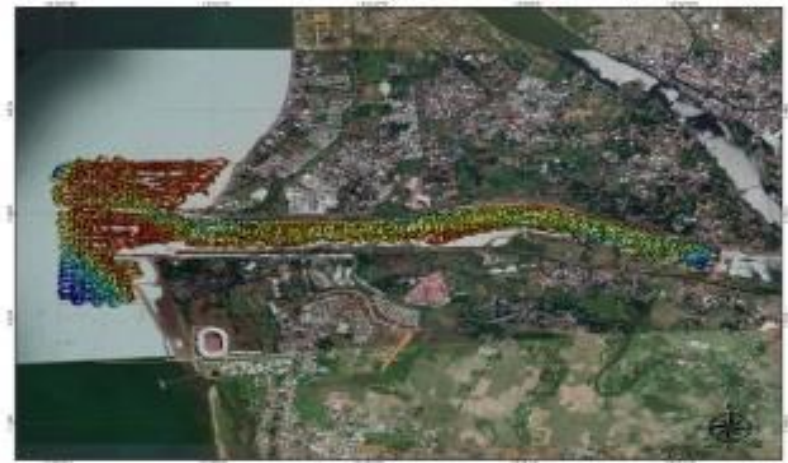

Gambar 4. Alur pengukuran batimetri menggunakan Echo Sounder Garmin 585 dan transducer

\subsection{Pengamatan Arus, Salinitas dan Suhu}

Pengamatan dilakukan di 18 stasiun pada 6 penampang melintang sungai di Muara Sungai Jeneberang hingga masuk ke down stream Sungai Jeneberang. Posisi pengamatan pada kedalaman 0,2d; 0,6d; 0,8d dari permukaan air. Pengamatan dilakukan pada saat spring tide dan neap tide di bulan yang sama.

\subsection{Pemetaan dengan aplikasi ArcGis}

Tahapan dalam pengolahan data menggunakan tools Sistem Informasi Geografis/Geographic Infromation System (ArcGis) terdiri atas INPUT, PROSES (Pengolahan, Analisis dan Penyimpanan Data) serta OUTPUT (Layout). INPUT data dalam GIS dapat diperoleh dari hasil pengukuran lapangan (survei teristris, fotogrametri dan survei hidrografi), peta analog/peta cetak dan melalui proses scanning serta data yang bersumber dari citra satelit. Tahapan umum dalam pembuatan peta menggunakan tools software ArcGis adalah sebagai berikut. 


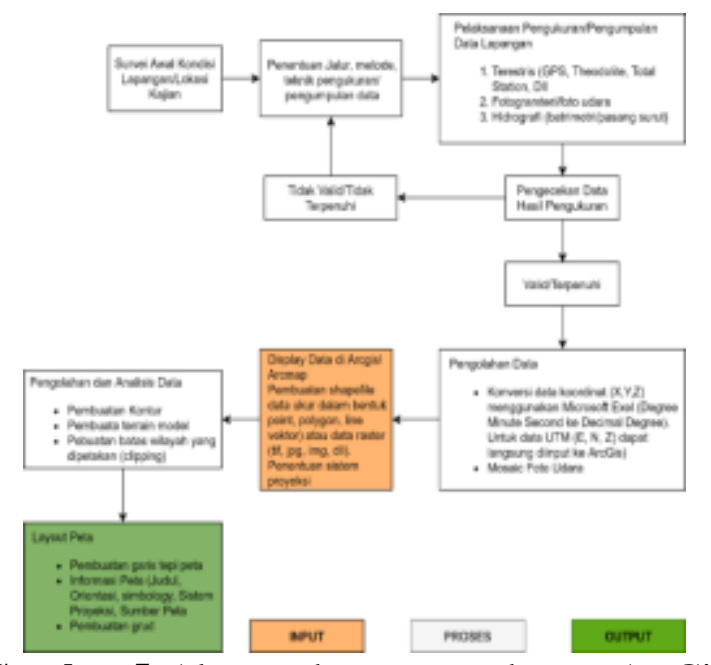

Gambar 5. Alur pembuatan peta dengan ArcGis

\section{Hasil dan Pembahasan}

\subsection{Pengolahan dan Analisis data Spasial Bathimetri}

Hasil pengukuran Echo Sounder kemudian di download dalam excel yang kemudian dikoreksi dengan data pengamatan pasang surut pada logger dan kedalaman transducer sehingga didapatkan nilai kedalaman sebenarnya seperti pada gambar 7. Nilai kedalaman yang sudah didapat kemudian di proses dengan software ArcGIS untuk dilakukan interpolasi Topo to Raster pada ArcToolbox. Parameter yang digunakan yaitu Polygon badan sungai sebagai Boundary, Polyline Garis Sungai sebagai contour 0, dan titik pengukuran Echo Sounder sebagai Point Elevation dengan ukuran cell sebesar 5 meter sehingga didapatkan profil dasar sungai atau perairan dengan hasil yang detail seperti yang ditunjukkan pada gambar 8 .

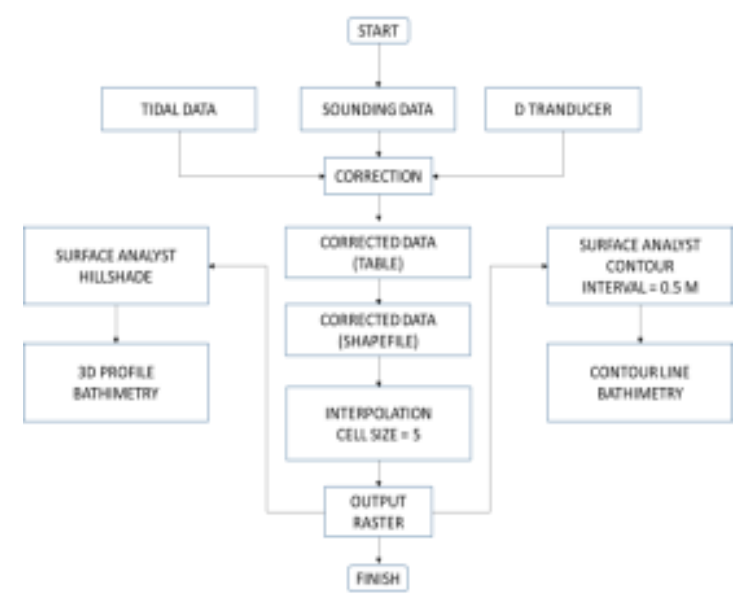

Gambar 6. Alur pengolahan data untuk pemetaan batimetri

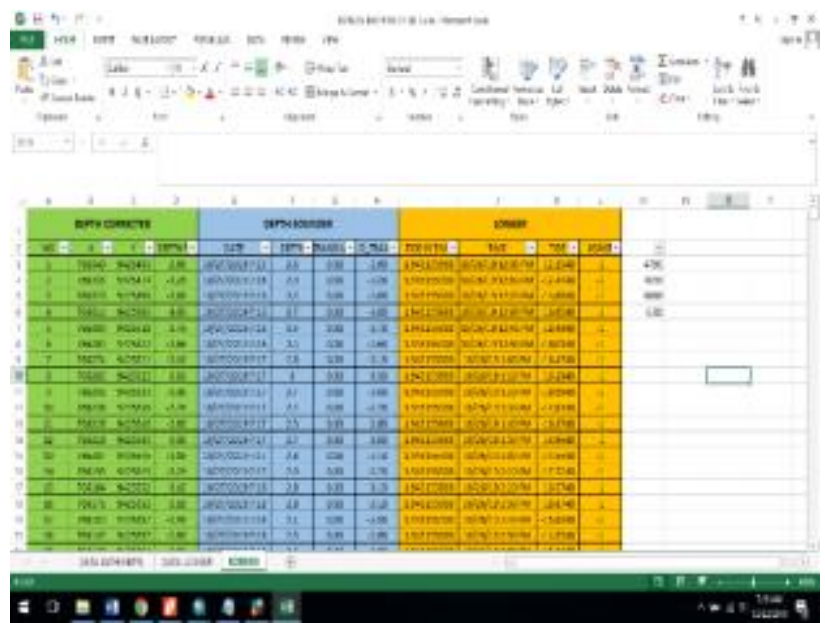

Gambar 7. Proses koreksi data pengukuran dengan data logger dan kedalaman transducer

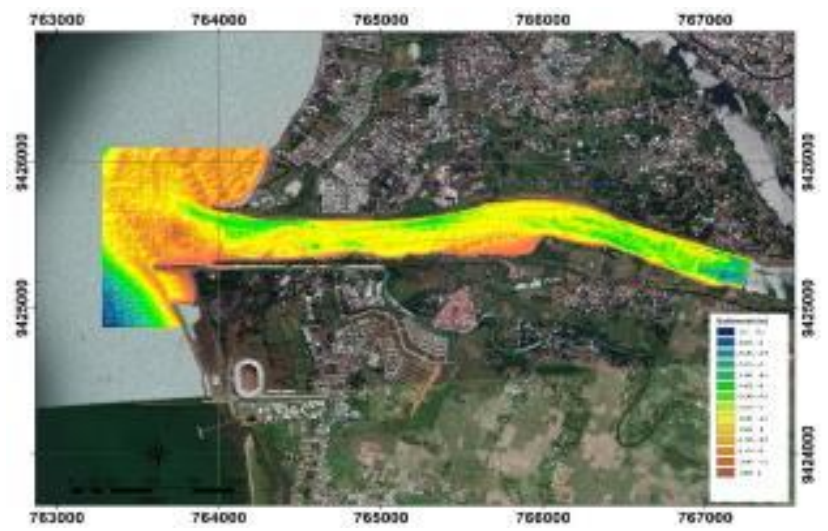

Gambar 8. Profil dasar perairan hasil pengukuran Echo Sounder setelah koreksi

Setelah dilakukan interpolasi maka akan didapatkan data profil dasar sungai. Untuk mendapatkan garis contour, maka dilakukan proses ekstraksi data dengan menggunakan tools spatial analyst - surface - Contour pada gambar. Interval yang digunakan yaitu 0.5 meter sehingga didapatkan hasil seperti pada gambar 10 .

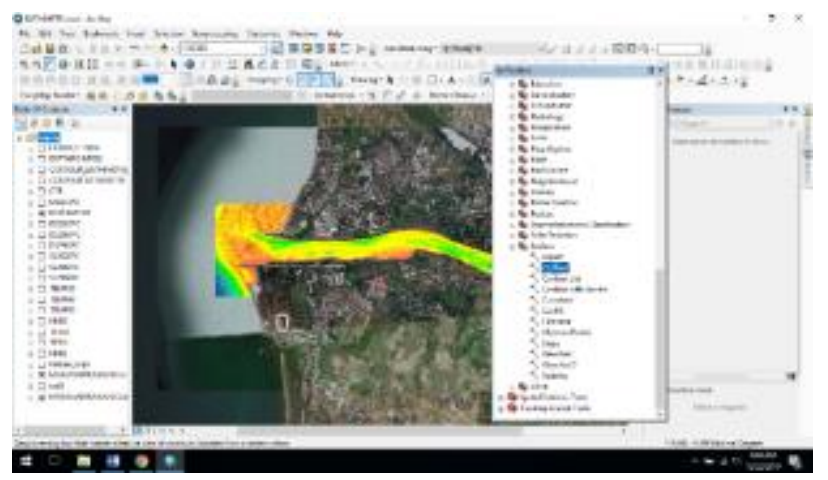

Gambar 9. Ekstraksi garis kontur menggunakan Tools Contour 


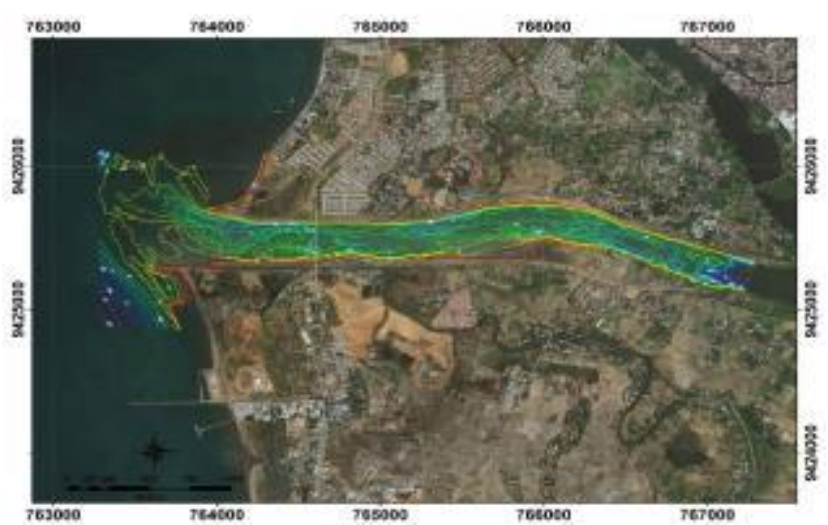

Gambar 10. Hasil Ekstraksi Garis kontur

\subsection{Pengolahan dan Analisis Data Spasial Hasil Pengukuran Massa Air}

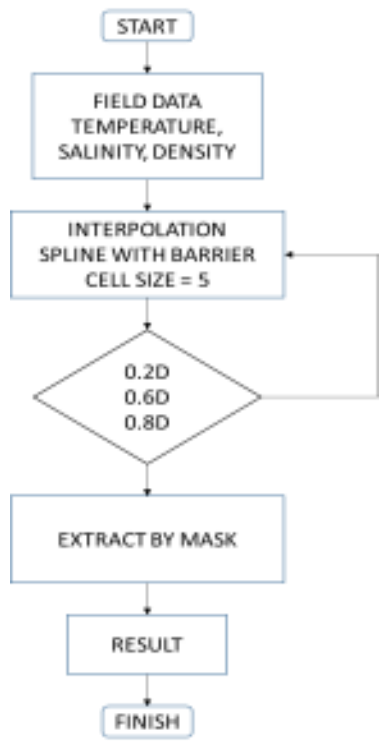

Gambar 11. Alur pengolahan data untuk pemetaan struktur massa air

Hasil pengukuran dari alat CTD didapatkan logfile yang kemudian disortir seperti pada gambar 12 , untuk mendapatkan data pengukuran temperatur, salinitas dan densitas per hari selama 15 hari. Data tersebut disajikan dalam bentuk tabulasi excel yang kemudian dijadikan sebagai data dasar seperti pada gambar 13. Data dasar yang telah dibuat kemudian diinterpolasi dengan metode spline with barrier pada software ArcGIS dengan ukuran cell 5 meter agar didapatkan hasil yang detail seoerti pada gambar 14 . Proses interpolasi dilakukan sebanyak tiga kali pada tiga kedalaman perairan, yaitu $0.2 \mathrm{D}, 0.6 \mathrm{D}$ dan $0.8 \mathrm{D}$ untuk menghasilkan pola sebaran temperatur, salinitas dan densitas pada tiga lapisan perairan. Setelah semua poses interpolasi dilakukan, maka akan didapatkan data raster yang kemudian dilakukan ekstraksi pada area yang sudah ditentukan seperti pada gambar 15 .

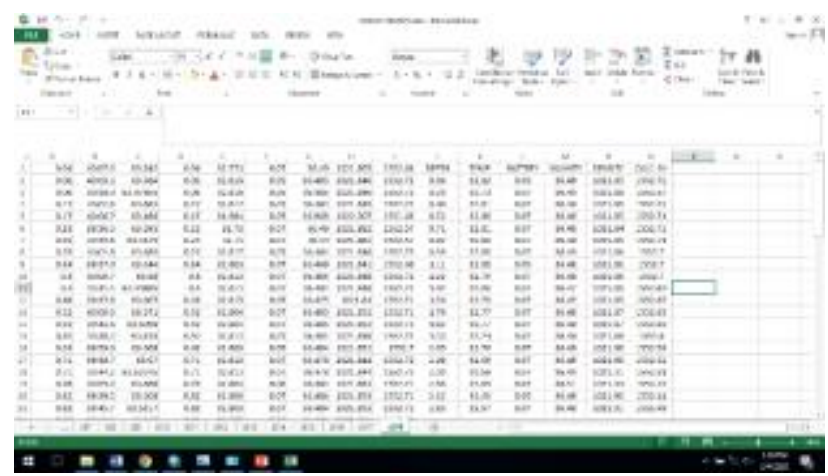

Gambar 12. Proses Sorting data per hari di 18 Stasiun pengamatan

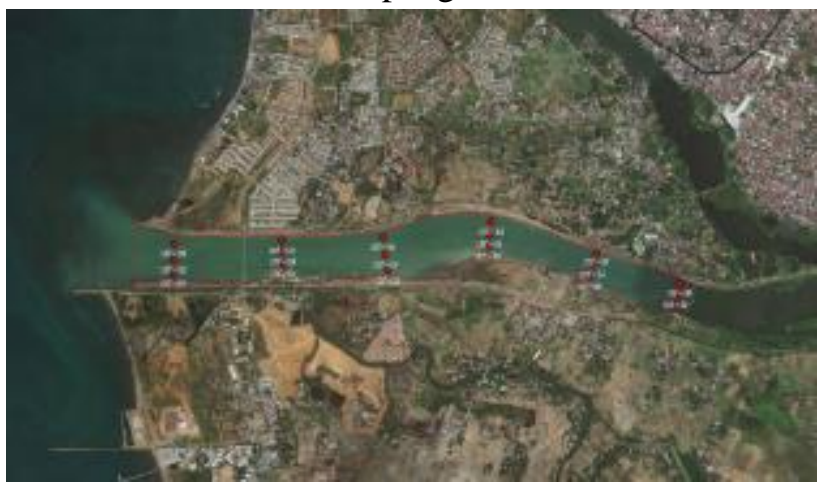

Gambar 13. Ploting Data dasar

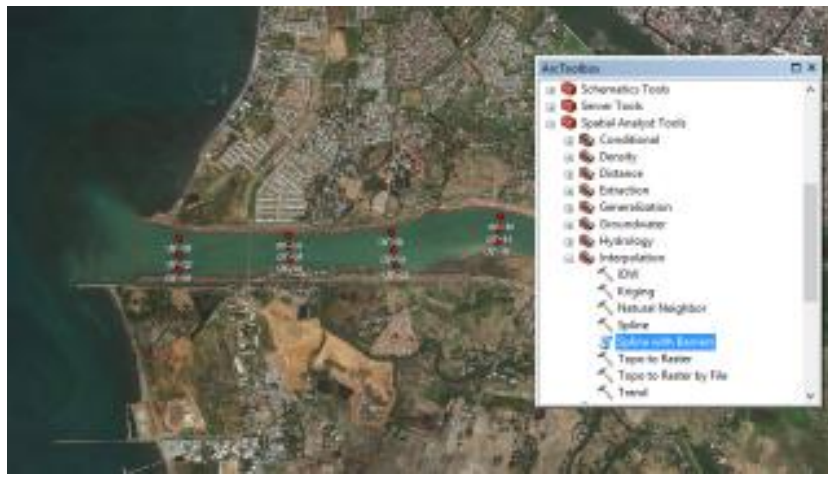

Gambar 14. Proses Interpolasi

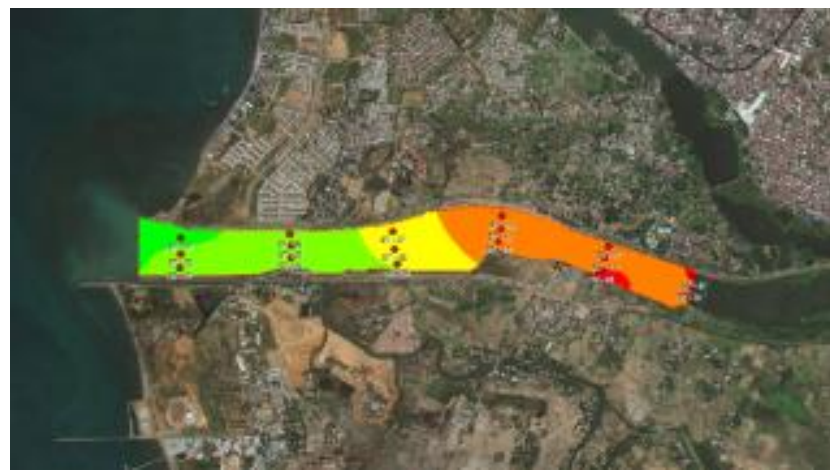

Gambar 15. Hasil Interpolasi data Temperatur, salinitas dan densitas 


\subsection{Hasil Pemetaan Sebaran Struktur Massa Air}

Hail pemetaan spasial sebaran struktur massa air pada muara Sungai Jeneberang diperlihatkan pada dua kondisi yaitu pada saat spring tide dan neep tide.Pemetaan spasial ini juga menggambarkan sebaran struktur massa air pada saat pasang menuju surut dan pada saat surut menuju pasang masing masing pada kondisi spring tide dan neep tide. Hasil pemetaan sebaran struktur massa air dapat dilihat pada gambar 16,17,18, dan 19.

Berdasarkan analisis data pengukuran salinitas di Muara Sungai Jeneberang, diperoleh salinitas berkisar antara 33 sampai dengan 36 PSU, kondisi tertinggi ditemukan pada saat surut menuju pasang, berada pada sisi Timur sungai yang meninggi dengan interval berkisar 36,51 PSU. Tingkat salinitas pada daerah pesisir dekat dengan mulut muara memiliki salinitas sebesar 34,51 PSU sampai dengan 35 PSU, seperti pada gambar 16 dan 17.
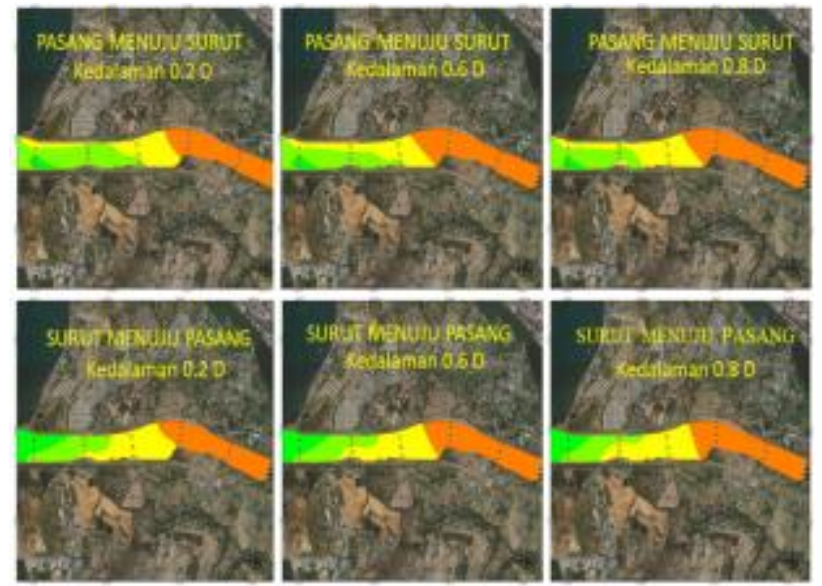

Gambar 16. Sebaran salinitas pada kondisi Spring Tide
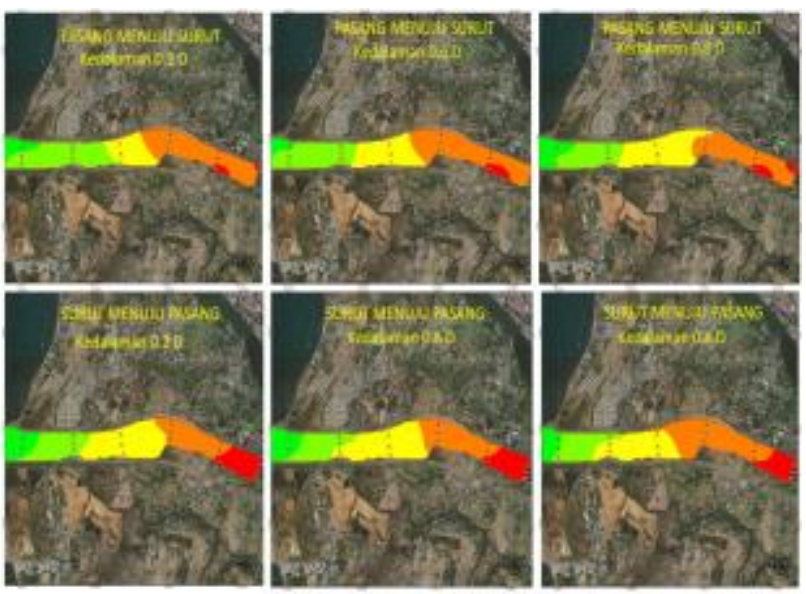

Gambar 17. Sebaran salinitas pada kondisi Neep Tide
Berdasarkan analisis data pengukuran temperatur di Muara Sungai Jeneberang, diperoleh temperatur berkisar antara $29,5-33,2^{\circ} \mathrm{C}$. Temperatur maksimum di daerah muara Sungai Jeneberang adalah $32^{\circ} \mathrm{C}$ temperatur rata-rata adalah $31{ }^{\circ} \mathrm{C}$ dan temperatur minimum adalah $29,6{ }^{\circ} \mathrm{C}$. Temperatur maksimum di daerah hulu daerah penelitian di sungai Jeneberang adalah $33,2^{\circ} \mathrm{C}$ temperatur rata-rata adalah $32,5^{\circ} \mathrm{C}$ dan temperatur minimum adalah $31,2^{\circ} \mathrm{C}$.

Temperatur di perairan Muara Sungai Jeneberang menunjukkan pola temperatur lebih rendah di daerah mulut muara dan temperatur lebih tinggi di daerah hulu sampai dengan bendung karet Sungai Jeneberang. Berdasarkan pengamatan temperatur dasar perairan dengan ADCP diperoleh temperatur di stasiun 1 lebih tinggi dari pada temperatur di stasiun 2.
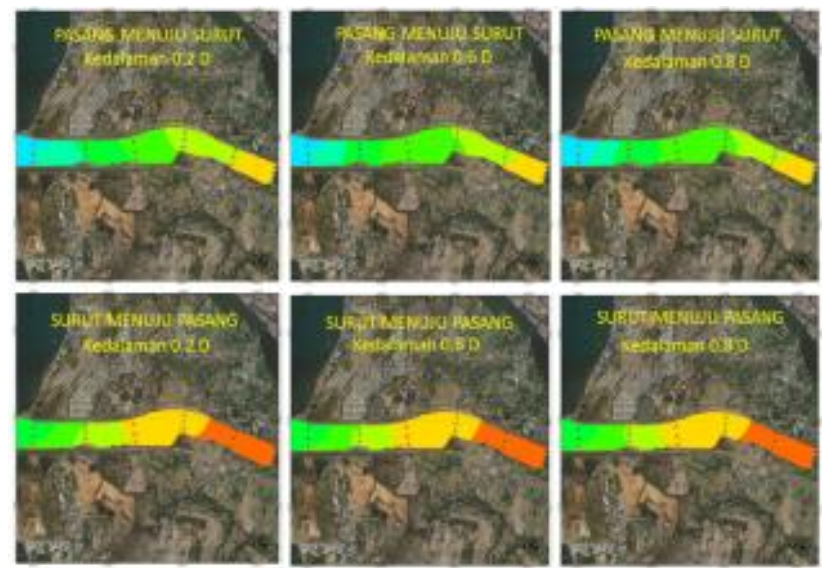

Gambar 18. Sebaran Suhu pada kondisi Neep Tide
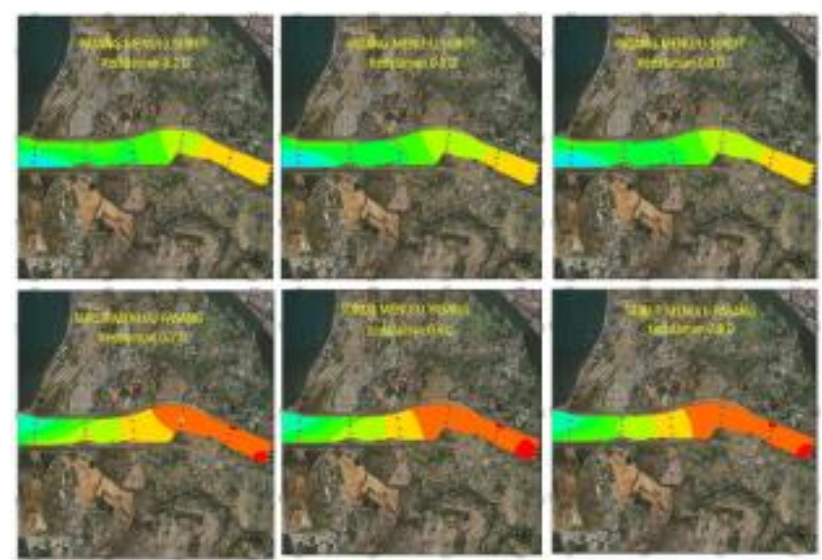

Gambar 19. Sebaran suhu pada kondisi Spring Tide

Selisih maksimal temperatur yang teramati adalah $3,1^{\circ} \mathrm{C}$, dengan rata-rata selisih temperatur adalah 1,21 ${ }^{\circ} \mathrm{C}$, dan selisih temperatur minimum adalah $0,10^{\circ} \mathrm{C}$.

\section{Kesimpulan}

Hasil pemetaan memperlihatkan pola sebaran dan stratifikasi struktur massa air di Muara Sungai 
Jeneberang. Pola sebaran dan pelapisan massa air ini diperlihatkan secara spasial pada saat spring tide dan neep tide, pada kondisi pasang menuju surut dan kondisi surut menuju pasang. Pola sebaran struktur massa air secara spasial ini perlu ditambahkan dengan memperlihatkan pola sebabarannya secara vertical, sehingga dapat melihat profil kolom air dan kondisi pencampuran yang terjadi akibat pengaruh pasang surut.

\section{DAFTAR PUSTAKA}

[1]. Rositasari, Ricky dan Rahayu, Sri Kusdi , 1994 Sifat-Sifat Estuary dan Pengelolaannya. Jakarta. 0216-1877 ISSN Oseana Volume XIX No.3 2131

[2]. Tubalawony,S.,Tuahattu,J.W.,dan Wattimena,S.M. 2008. Karakteristik fisik massa airPermukaan Teluk Ambon Bulan Juli. Fak. Perikanan dan Ilmu Kelautan. Umpatti

[3]. Karamma, Sukri. 2018. Pemodelan Pasang Surut Terhadap Surf Zone Menggunakan Surfer, FortranC++ dan Gis pada Pantai Kota Makassar. Kendari. SemanTIK, Vol.4, No.2.

[4]. Hatayama, T. 2004. Transformation of the Indonesian Throughfow water by vertical mixing and it relation to tidal generated internal wave. $J$. Oceanogr. 60:569-585.

[5]. Nurhayati. 2006. Distribusi Vertical Suhu, Salinitas dan Arus di perairan Morotai, Maluku Utara, Oseanologi dan Limnologi Laut, Pusat Penelitian Oseanigrafi-LIPI

[6]. Furqon, A. M. 2007. Tipe Estuari Binuangeun (Banten) Berdasarkan Distribusi Suhu dan Salinitas Perairan. Oseanologi dan Limnologi. Indonesia

[7]. B. Bakri, A. Sumakin, Y. Widiasari, and M. Ihsan, "Distribution pattern of water salinity analysis in Jeneberang river estuary using ArcGIS," IOP Conf. Series: Earth and Environmental Science, vol. 419, p. 012116, Feb. 2020, doi: 10.1088/1755-1315/419/1/012116. 